\title{
Polycationic Polypeptides: a Possible Model for the Penetration-enhancing factor in the Invasion of Host Cells by Toxoplasma gondii
}

\author{
By ROLAND WERK, ${ }^{*}+$ REINHARD DUNKER ${ }^{2}$ AND \\ SIEGFRIED FISCHER ${ }^{3}$ \\ ${ }^{1}$ Zentrum der Hygiene, Johann-Wolfgang-von-Goethe Universität, Paul-Ehrlich Strasse 40, \\ 6000 Frankfurt, Federal Republic of Germany \\ 2 Institute of Pathology and \\ ${ }^{3}$ Institute of Pharmaceutical Botany, University of Würzburg, Federal Republic of Germany
}

(Received 25 January 1983; revised 1 November 1983)

\begin{abstract}
The effect of polycationic polypeptides (polylysine, polyarginine and polyhistidine) on the invasion of mammalian cells and plant protoplasts by Toxoplasma gondii was studied. In JM cells, a human lymphoblastoid cell line with $\mathrm{T}$ cell characteristics, all polycationic polypeptides used increased the invasion rate in a concentration-dependent manner. This effect and the morphological changes revealed by electron microscopy resembled the action of the penetrationenhancing factor previously described by E. Lycke and co-workers. Plant protoplasts of Catharanthus roseus, which are resistant to $T$. gondii invasion, showed the same morphological changes in the presence of polycationic polypeptides as observed for JM cells, but were not invaded.
\end{abstract}

\section{INTRODUCTION}

The biochemical mechanism of host cell invasion by the parasite Toxoplasma gondii is still a matter of controversy. Lycke et al. (1975) reported on the isolation of a penetration-enhancing factor (PEF) with a molecular weight of about 70000 to 150000 . This factor increased the number of infected cells and induced distinct morphological alterations in the host cell. The PEF is believed to be secreted by specific organelles, the rhoptries, located in the anterior part of the parasite (Gustafson et al., 1954; Garnham et al., 1962). These organelles have an unusually high concentration of polycationic peptides (De Souza \& Souto-Padron, 1978). Morphological alterations of cells induced by polycationic polypeptides (PCP) have been reported (Mamelack et al., 1969; Hartmann \& Galla, 1978); Lycke et al. (1975) described similar features for the PEF. Moreover, Hughes \& van Knapen (1982) reported a secretory circulating antigen of Toxoplasma. This antigen, $\mathrm{Ag} \mathrm{5}$, is a basic protein which has an isoelectric point of 5.8 and a molecular weight of 324000 . The authors speculated that this protein, which is in part similar to the PEF, is released by the parasite during host cell entry (Hughes \& van Knapen, 1982).

In this study we examined the effect and invasion-enhancing capacity of polycationic polypeptides on the invasion of host cells by $T$. gondii. Plant protoplasts have been reported to be the only cell type resistant to infection by Toxoplasma parasites (Werk \& Fischer, 1982). There is at present no explanation for this finding; however, a different membrane structure might be responsible for the lack of infectivity of the Toxoplasma parasite to plant protoplasts (Evans, 1976). It was therefore of interest to study the effect of PCP on the invasion of protoplasts by $T$. gondii.

† Present address: Rottendorfer Str. 21, D-8700 Würzburg, FRG.

Abbreviations: Eagle's MEM, Eagle's minimal essential medium; PCP, polycationic peptides; PEF, penetration-enhancing factor. 


\section{METHODS}

Cells. The RH strain of Toxoplasma gondii was obtained from Dr H. Seeliger, Institut für Hygiene und Medizinische Mikrobiologie der Universität, Würzburg. Mice were infected intraperitoneally and the parasites were harvested from the peritoneal cavity three $\mathrm{d}$ post-infection. The trophozoites were washed three times with phosphate-buffered saline pH 7-2 (PBS) (Dulbecco \& Vogt, 1954) at room temperature, and collected by low-speed centrifugation at $1000 \mathrm{~g}$. JM cells were kindly provided by Dr H. W. Kreth, Institut für Virologie, Universität Würzburg. The JM cell line is a human lymphoblastoid cell line with T cell characteristics (Schneider et al., 1977). The cells were kept in a RPMI 1640 medium (Morgan, 1970) which had been supplemented with $10 \%$ (v/v) foetal calf serum, $50 \mu \mathrm{g} \mathrm{ml}^{-1}$ gentamicin, and $1 \%(\mathrm{w} / \mathrm{v})$ glutamine. HeLa cells, a gift of Dr G. May, Zentrum der Hygiene, Universität Frankfurt, were kept in Eagle's minimal essential medium (MEM) supplemented with 5\% (v/v) foetal calf serum, $50 \mu \mathrm{g}$ gentamicin $\mathrm{ml}^{-1}$, and $1 \%(\mathrm{w} / \mathrm{v})$ glutamine (all from Flow Laboratories). Plant protoplasts, of Catharanthus roseus, were prepared as previously described (Werk \& Fischer, 1982).

Infection assay. The experimental schedule including 'target' and 'effector' cell specificity, the ratio of 'target' cells to 'effector' cells, and the concentration of the PCP is shown in Table 1. Polylysine (mol. wt 400000), polyhistidine (7000) and polyarginine (130000) (Sigma) were used. The assay for JM cells and protoplasts was done in $1 \mathrm{ml}$ RPMI medium without foetal calf serum, and with or without PCP for $30 \mathrm{~min}$ at $37^{\circ} \mathrm{C}$. At the end of the incubation period samples were prepared as smears on glass slides and examined by phase-contrast light microscopy at $500 \times$ magnification. The infection rate was assayed as percentage of infected cells. For each value at least 300 cells were analysed and three parallel replicate experiments were conducted.

Control experiments including tests for polypeptide-induced phagocytosis and test for viability of 'target' and 'effector' cells are shown in Table 2 . Since JM cells are not very suitable for observing parasite rosette-colony formation after multiple infection, HeLa cells were used for control experiments. Overnight HeLa cell coverslip cultures were infected with $T$. gondii in the presence or absence of polypeptides for $30 \mathrm{~min}$ at $37^{\circ} \mathrm{C}$. The cultures were then carefully rinsed with Eagle's MEM to remove free parasites. Cells were incubated in $10 \mathrm{ml}$ fresh Eagle's MEM without foetal calf serum, to prevent HeLa cell proliferation, for $18 \mathrm{~h}$ at $37^{\circ} \mathrm{C}$. The cultures were examined microscopically and the infection was quantified by expressing the number of parasite colonies as a percentage of the number of 'target' cells. HeLa cell coverslip cultures incubated with viable or heat-killed yeast cells (Saccharomyces cerevisiae) were examined directly after the infection period of $30 \mathrm{~min}$.

Electron microscopy. To examine ultrastructural changes due to the PCP, $3.3 \times 10^{6} \mathrm{JM}$ cells were treated with 10 or $100 \mathrm{ng} \mathrm{ml}^{-1}$ of each of polyhistidine, polylysine and polyarginine, and infected for 30 min with $1.2 \times 10^{6}$ Toxoplasma trophozoites. Cells were collected by centrifugation and fixed with $5 \%(\mathrm{w} / \mathrm{v})$ glutaraldehyde in PBS, post-fixed with $1 \%$ osmium tetroxide and embedded in Epon by the procedure of Luft (1961). Sections were cut on a Reichert OM3 ultramicrotome and stained with uranyl acetate and lead citrate, and were examined in a Zeiss EM 10 electron microscope.

\section{RESULTS}

By comparison with controls, the infection rate of JM cells in the presence of polylysine, polyhistidine and polyarginine increased with PCP concentration over a range of 0.5 to $10.0 \mathrm{ng} \mathrm{ml}^{-1}$ (Table 1). Polylysine, at the highest concentration used, caused an increase in infection rate to $39.6 \%$ as compared to the standard infection rate of $17 \%$. The infection rate at the corresponding concentration of polyhistidine and polyarginine was assayed to be increased to $34 \%$ and $37 \%$ respectively (Table 1 ). Plant protoplasts previously shown to be resistant to infection by $T$. gondii were also used as target cells, but even in the presence of $100 \mathrm{ng} \mathrm{PCP} \mathrm{ml}{ }^{-1}$ no infected cells were found (Table 1). Control experiments for stimulated phagocytosis were done. PCP did not stimulate the uptake of viable or heat-killed yeast cells by JM or HeLa cells (Table 2).

Severe structural damage in most JM cells at a PCP concentration of $10 \mathrm{ng} \mathrm{ml}^{-1}$ was revealed by electron microscopy. The effect of polylysine was especially strong, whereas polyhistidine showed less severe alterations at the same concentration. The cytoplasm of treated cells showed various stages of vacuole formation and a wide range of disorganization (Fig. 1). At high concentrations ( $100 \mathrm{ng} \mathrm{PCP} \mathrm{ml}^{-1}$ ) severe plasma membrane damage was apparent. The nucleus showed partial condensation of chromatin (Fig. 2).

The parasite also showed essentially similar morphological modifications including stripping of the pellicle at $100 \mathrm{ng} \mathrm{PCP} \mathrm{ml} l^{-1}$ (Fig. 3). The results of the uptake experiments (Tables 1 and 2) revealed that at PCP concentrations up to $10 \mathrm{ng} \mathrm{ml}^{-1} T$. gondii was able to multiply intracellularly. There was no difference between infected and uninfected cells in the degree or type of 
Table 1. Infection experiments with T. gondii in the presence of PCPS

JM cells or plant protoplasts were exposed to $T$. gondii in the presence of PCPs at the concentrations shown.

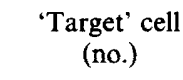

JM cells

$\left(3.5 \times 10^{5}\right)$
'Effector' cell

(no.)

Toxoplasma gondii

$\left(1.2 \times 10^{6}\right)$

Catharanthus roseus $\left(10^{5}\right)$

Toxoplasma gondii

$\left(2 \times 10^{6}\right)$

\begin{tabular}{|c|c|c|}
\hline PCP & $\begin{array}{l}\text { PCP concn } \\
\left(\mathrm{ng} \mathrm{ml}^{-1}\right)\end{array}$ & $\begin{array}{c}\text { Percentage infection } \\
\text { of 'target' cells } \\
( \pm \mathrm{SE})\end{array}$ \\
\hline None & - & $17 \cdot 0 \pm 3.5$ \\
\hline Polylysine & $\begin{array}{r}0.5 \\
1.0 \\
5.0 \\
10.0\end{array}$ & $\begin{array}{l}20 \cdot 3 \pm 5 \cdot 0 \\
27 \cdot 6 \pm 2 \cdot 6 \\
36 \cdot 6 \pm 4 \cdot 6 \\
39 \cdot 6 \pm 3 \cdot 0\end{array}$ \\
\hline Polyarginine & $\begin{array}{r}0.5 \\
1.0 \\
5 \cdot 0 \\
10 \cdot 0\end{array}$ & $\begin{array}{l}19.6 \pm 3.6 \\
21.6 \pm 5.6 \\
24.0 \pm 7 \cdot 0 \\
37.0 \pm 4.6\end{array}$ \\
\hline Polyhistidine & $\begin{array}{r}0.5 \\
1.0 \\
5 \cdot 0 \\
10 \cdot 0\end{array}$ & $\begin{array}{c}19.6 \pm 4.6 \\
\text { NT } \\
24 \cdot 5 \pm 6.5 \\
34 \cdot 0 \pm 5 \cdot 0\end{array}$ \\
\hline $\begin{array}{l}\text { Polylysine } \\
\text { Polyarginine } \\
\text { Polyhistidine }\end{array}$ & $\begin{array}{r}0 \cdot 0 \\
1 \cdot 0 \\
10 \cdot 0 \\
100 \cdot 0\end{array}$ & 0.0 \\
\hline
\end{tabular}

NT, Not tested.

Table 2. Experiments to test for PCP-induced phagocytosis in HeLa or JM cells

HeLa cells or JM cells were exposed to Toxoplasma gondii or Saccharomyces cerevisiae. Development of Toxoplasma trophozoites in HeLa cells and uptake of viable and heat-killed cells are shown as number of 'effector' cells per 100 'target' cells.

\begin{tabular}{|c|c|c|c|c|}
\hline $\begin{array}{l}\text { 'Target' cell } \\
\text { (no.) }\end{array}$ & $\begin{array}{l}\text { 'Effector' cell } \\
\text { (no.) }\end{array}$ & PCP & $\begin{array}{l}\text { PCP concn } \\
\left(\mathrm{ng} \mathrm{ml}^{-1}\right)\end{array}$ & $\begin{array}{c}\text { No. of } \\
\text { 'effector' cells } \\
\text { per } 100 \\
\text { 'target' cells } \\
( \pm \mathrm{SE})\end{array}$ \\
\hline \multirow[t]{6}{*}{$\begin{array}{l}\text { HeLa cells } \\
\left(5 \times 10^{5}\right)\end{array}$} & \multirow{6}{*}{$\begin{array}{l}\text { Toxoplasma gondii } \\
\left(2 \times 10^{6}\right)\end{array}$} & None & - & $53 \cdot 0 \pm 3 \cdot 0$ \\
\hline & & Polylysine & $\begin{array}{r}2 \\
5 \\
10\end{array}$ & $\begin{array}{c}65 \cdot 8 \pm 4 \cdot 8 \\
84 \cdot 6 \pm 5 \cdot 4 \\
>90\end{array}$ \\
\hline & & Polyarginine & $\begin{array}{l}2 \\
5\end{array}$ & $\begin{array}{l}65 \cdot 2 \pm 3 \cdot 2 \\
82 \cdot 1 \pm 6 \cdot 1\end{array}$ \\
\hline & & & 10 & $>\overline{9} 0$ \\
\hline & & Polyhistidine & 2 & $\begin{array}{l}61 \cdot 0 \pm 5 \cdot 0 \\
78 \cdot 8 \pm 4 \cdot 8\end{array}$ \\
\hline & & & $\begin{array}{r}5 \\
10\end{array}$ & $>>90$ \\
\hline \multirow{2}{*}{$\begin{array}{l}\text { HeLa cells } \\
\left(5 \times 10^{5}\right)\end{array}$} & Saccharomyces cerevisiae* & Polylysine & \multirow{2}{*}{$\begin{array}{r}5 \\
10\end{array}$} & \multirow{2}{*}{$\begin{array}{l}0 \cdot 0 \\
0 \cdot 0\end{array}$} \\
\hline & $\begin{array}{l}\text { Viable }\left(10^{7}\right) \\
\text { Heat-killed }\left(10^{7}\right)\end{array}$ & $\begin{array}{l}\text { Polyarginine } \\
\text { Polyhistidine }\end{array}$ & & \\
\hline \multirow[t]{2}{*}{$\begin{array}{l}\text { JM-cells } \\
\left(5 \times 10^{5}\right)\end{array}$} & $\begin{array}{l}\text { Saccharomyces cerevisiae* } \\
\text { Viable }\left(10^{7}\right)\end{array}$ & $\begin{array}{l}\text { Polylysine } \\
\text { Polyarginine }\end{array}$ & \multirow{2}{*}{$\begin{array}{r}5 \\
10\end{array}$} & \multirow{2}{*}{$\begin{array}{l}0 \cdot 0 \\
0 \cdot 0\end{array}$} \\
\hline & Heat-killed $\left(10^{7}\right)$ & Polyhistidine & & \\
\hline
\end{tabular}

* Control experiments without PCP gave values of $0 \cdot 0$ for uptake.

morphological alterations following PCP treatment. All three PCPs induced marked membrane damage of Catharanthus roseus protoplasts (Fig. 4). Indeed, at high concentration (100 ng PCP $\mathrm{ml}^{-1}$ ) the plasmalemma disappeared. However, as indicated in Table 1 damage to the plant protoplast membrane did not result in invasion by Toxoplasma. 

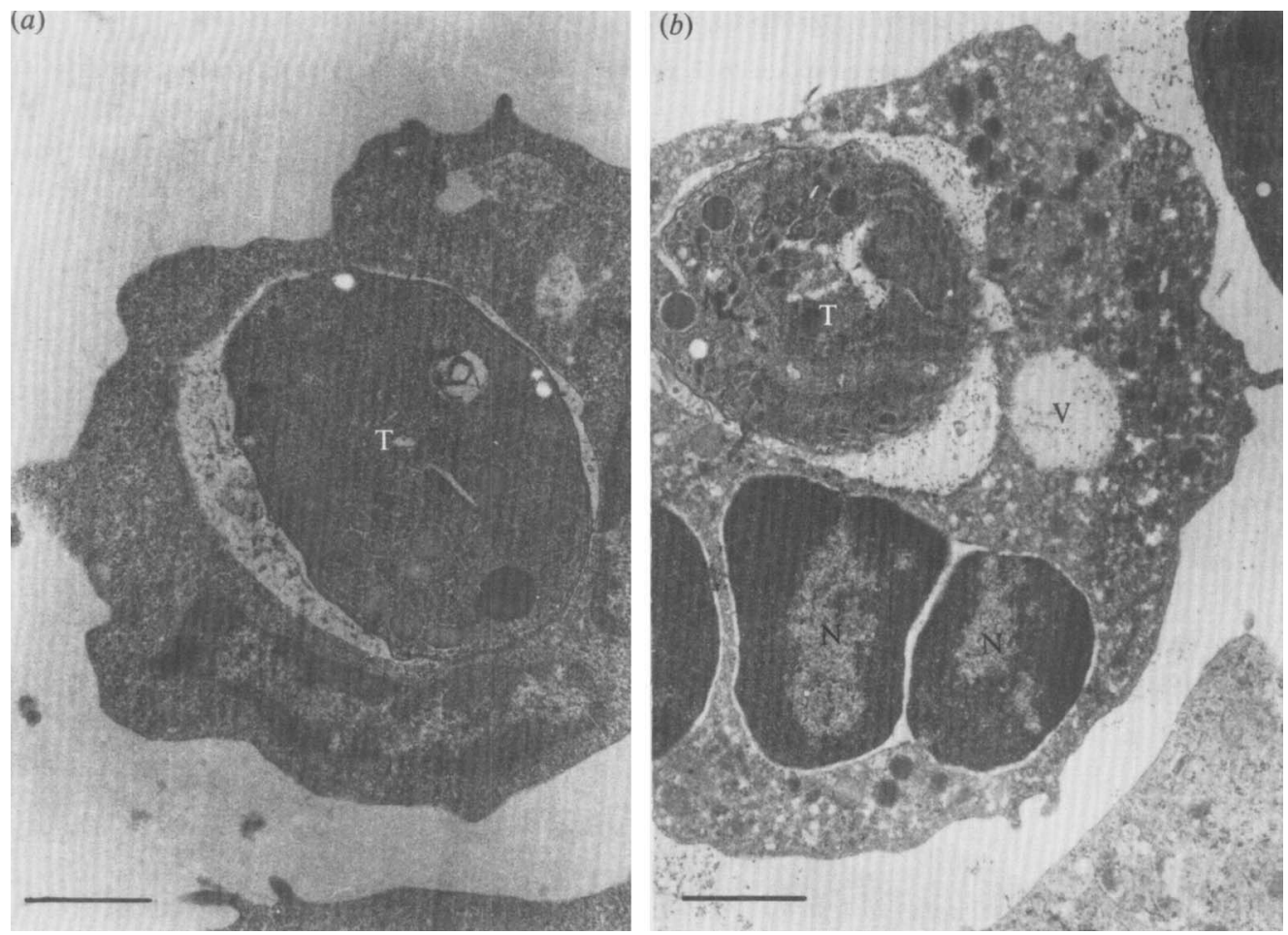

Fig. 1. Effect of polyhistidine on the invasion of JM cells by $T$. gondii. JM cells were exposed to $T$. gondii without polycationic polypeptides $(a)$ or in the presence of $10 \mathrm{ng}$ polyhistidine $\mathrm{ml}^{-1}(b)$. T, Toxoplasma gondii; $\mathrm{V}$, vacuole; $\mathrm{N}$, nucleus. Bar markers $1 \mu \mathrm{m}$.

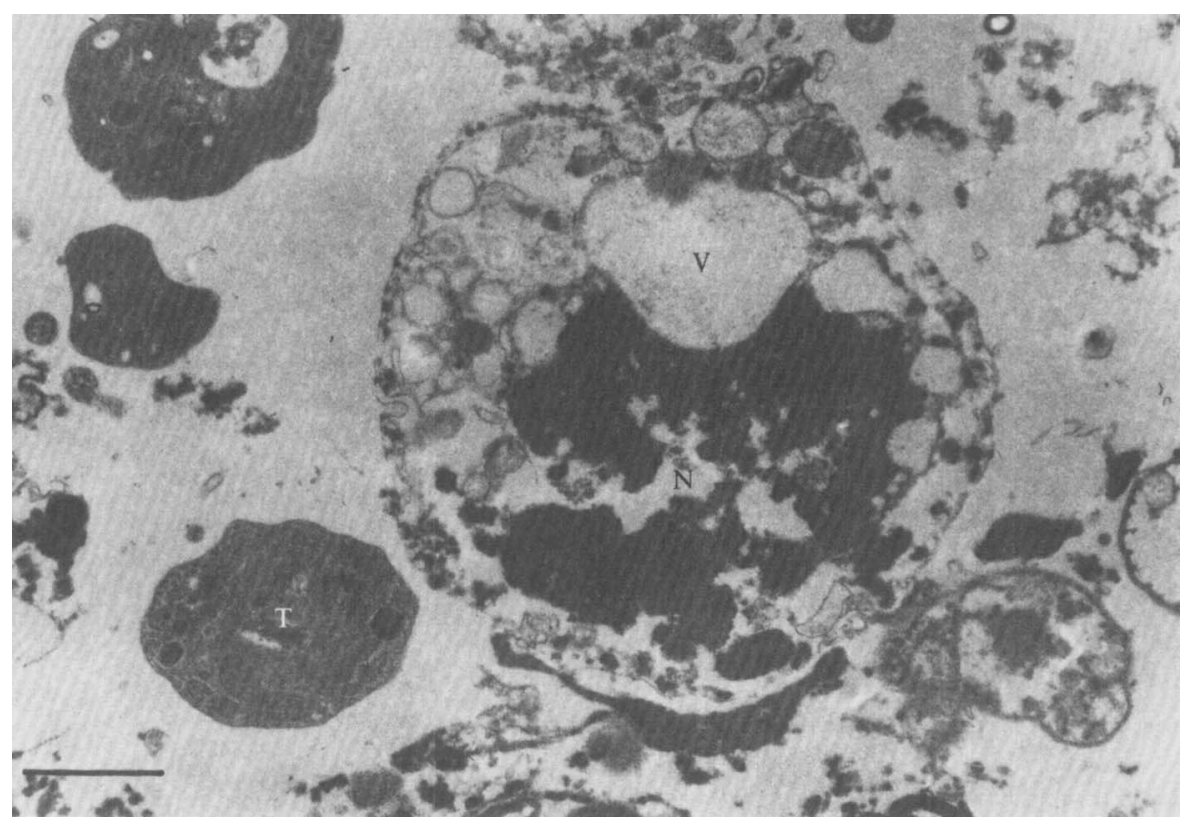

Fig. 2. Effect of polyarginine $\left(100 \mathrm{ng} \mathrm{m}^{-1}\right)$ on $\mathrm{JM}$ cells exposed to $T$. gondii. Note the extensive vacuolization of the cytoplasm and the condensation of the chromatin of both host and parasite cells. Abbreviations as in Fig. 1. Bar marker $1 \mu \mathrm{m}$. 


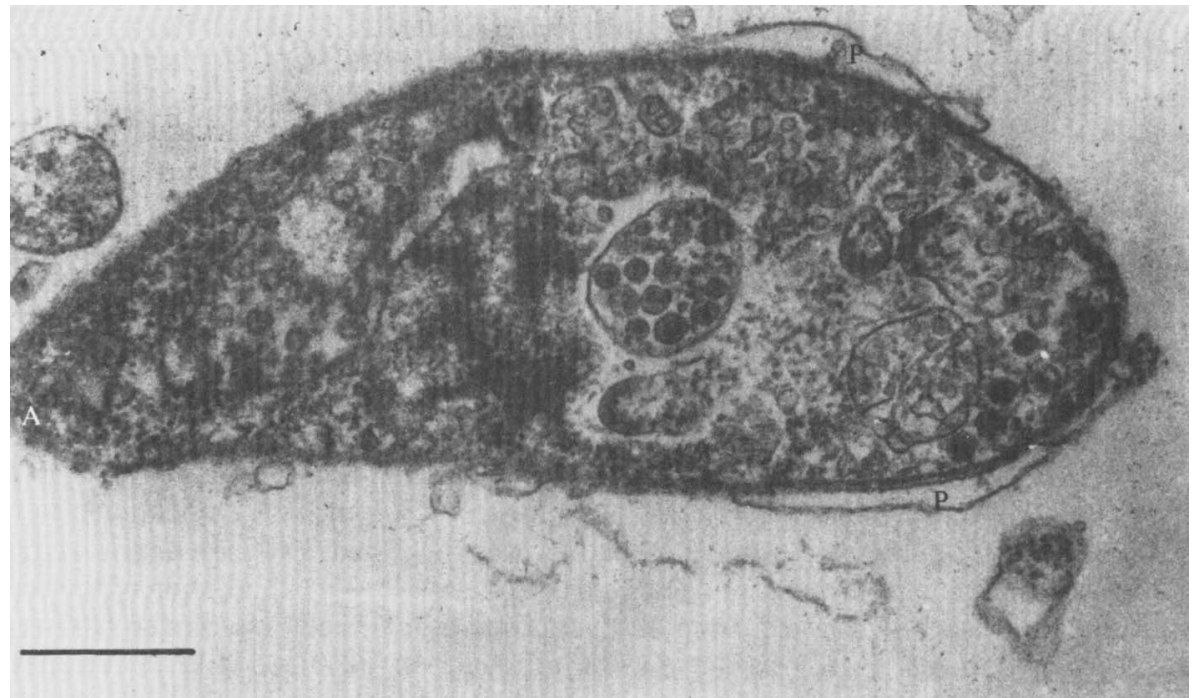

Fig. 3. Effect of polylysine (100 $\left.\mathrm{ng} \mathrm{m}^{-1}\right)$ on $T$. gondii trophozoites. Note the stripping of the pellicle. A, apical pole; P, pellicle. Bar marker $1 \mu \mathrm{m}$
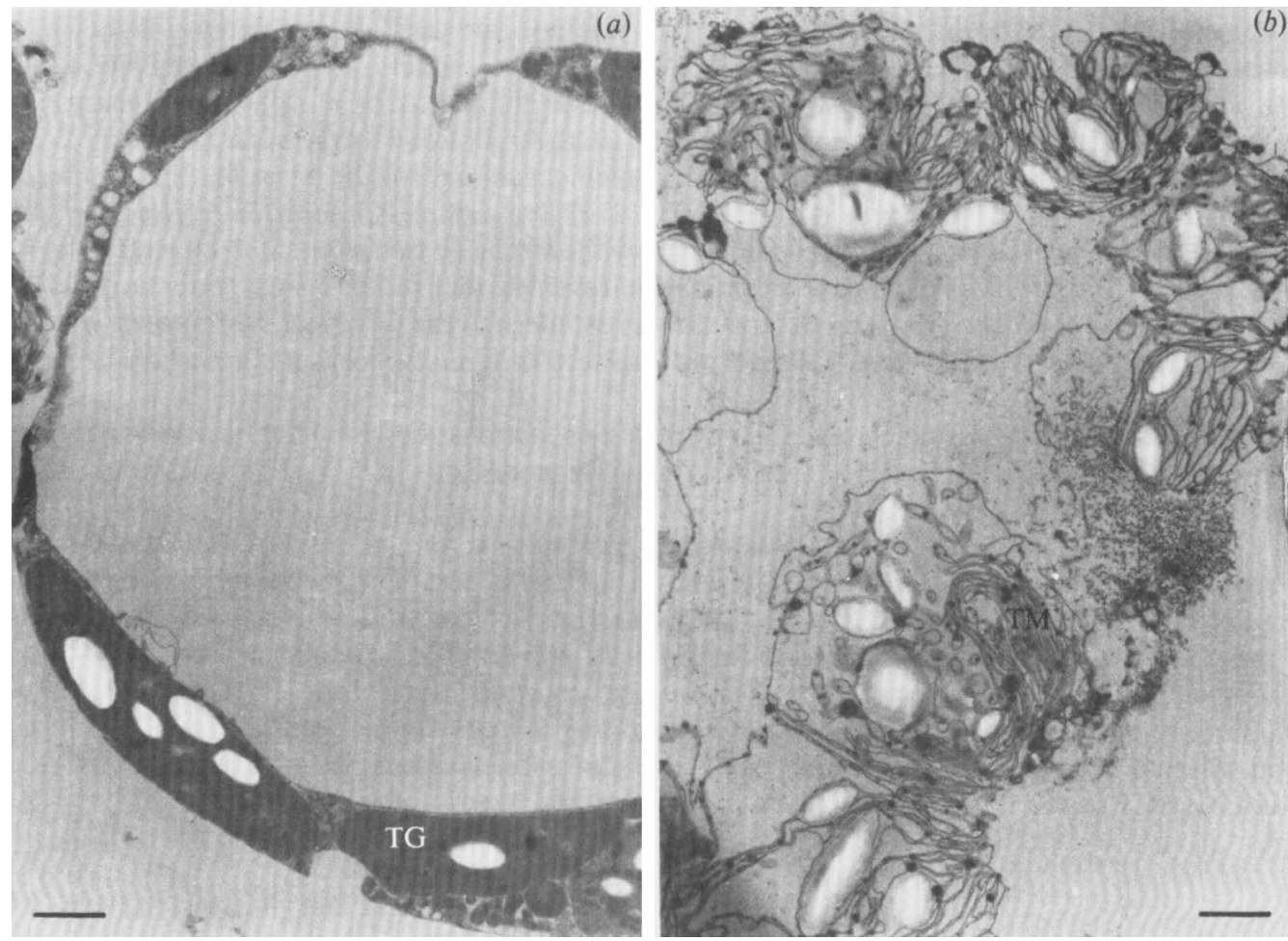

Fig. 4. Effect of polylysine on plant protoplasts. Protoplasts of Catharanthus roseus were exposed to $T$. gondii without basic polypeptides $(a)$ or in the presence of $100 \mathrm{ng}$ polylysine $\mathrm{ml}^{-1}(b)$; no invasion was detected. At this concentration of polylysine nearly all protoplasts exhibited destruction of the plasmalemma and the thylakoid membranes. TG, thylakoid granule; TM, thylakoid membranes. Bar markers $1 \mu \mathrm{m}$. 


\section{DISCUSSION}

The PEF described by Lycke et al. (1975) for Toxoplasma gondii is a protein with a molecular weight of 70000 to 150000 and is probably secreted by the rhoptries (Norrby, 1970). The physiological effect of the PEF is reported to be enhanced parasite invasion into target cells, which then undergo severe structural alterations. These changes resemble the action of polycationic polypeptides on target cells, as reported, for example, by Mamelack et al. (1969) using polylysine in toad bladder cells. The exact chemical nature of the PEF is, however, unknown. Experiments by De Souza \& Souto-Padron (1978) suggested that the PEF might be a polycationic protein: phosphotungstic acid staining, known to bind preferentially to PCPs (e.g. polyhistidine), revealed rhoptries containing an unusually high concentration of basic proteins. Recently, Hughes \& van Knapen (1982) demonstrated a secretory circulating antigen in acute toxoplasmosis, which they isolated from Toxoplasma trophozoites. The protein is basic. The authors suggested that this protein may participate in the invasion events.

A histidine-rich protein isolated by Kilejian (Kilejian \& Jensen, 1977) was shown to induce invagination of the erythrocyte plasmalemma and it was suggested, although not proved, that it participates in malaria parasite invasion (Bannister et al., 1977). An explanation of the action of polycationic substances is derived from the experiments of Sheetz \& Singer (1974). They observed changes in the microviscosity and morphology of red blood cell membranes after exposure to cationic substances. Based on these results Bannister et al. (1977) suggested that the histidine-rich protein either introduced energy dependent alterations of membrane proteins or changed the membrane microviscosity by intercalation with the lipid bilayer, and that this would result in an inward extension of the membrane.

Each of the three PCPs tested in this study increased the infection rate over the range 0.5 to $10.0 \mathrm{ng}$ PCP $\mathrm{ml}^{-1}$. This indicated that the invasion-enhancing effect of the PCPs is concentration dependent. However, the effect was not due to PCP-stimulated phagocytosis, since viable and heat-killed yeast cells were not internalized either by JM cells or by HeLa cells in the presence of PCPs. The physiological effect was accompanied by morphological changes of the target cells. Electron micrographs revealed severe structural damage such as vacuolization and stripping of the membrane as well as morphological changes of the parasite. PEF produced similar alterations of HeLa cells (Lycke et al., 1975). Nevertheless, the trophozoites were still able to invade host cells. The data presented show the strongest invasion-enhancing effect to be at $10 \mathrm{ng} \mathrm{PCP} \mathrm{ml} \mathrm{m}^{-1}$. Morphological examination revealed that the parasites were damaged to some extent at this concentration, but to a far less extent than the target cells. Moreover, uptake experiments demonstrated that PCPs did not interfere with multiplication of parasites in HeLa cells.

The similarities of physiological and morphological actions shown by the basic polypeptides and the PEF prompt us to suggest them as a possible model for the PEF. This does not imply a chemical similarity.

Werk \& Fischer (1982) reported that plant protoplasts were the only cell line definitely resistant to infection by $T$. gondii. A different membrane structure might be responsible for this resistance (Evans, 1976). Polylysine, polyhistidine and polyarginine caused the typical morphological changes reported above for JM cells. Nevertheless, Toxoplasma parasites failed to invade protoplasts in the presence of low or high concentrations of these polypeptides. Since plant protoplasts remained refractory to invasion by Toxoplasma it seems that PCP-induced membrane changes are not sufficient to ensure successful invasion. It has to be assumed that additional factors, missing from plant protoplasts, are necessary for invasion.

\section{REFERENCES}

Bannister, L. H., Butcher, G. A. \& Mitchell, G. H. (1977). Recent advances in understanding the invasion of erythrocytes by merozoites of Plasmodium knowlesi. Bulletin of the World Health Organization 55, 163-169.
De Souza, W. \& Souto-Padron, T. (1978). Ultrastructural localization of basic proteins on the conoid, rhoptries and micronemes of Toxoplasma gondii. Zeitschrift für Parasitenkunde 56, 123-129.

Dulbecco, R. \& VoGT, M. (1954). Plaque formation 
and isolation of pure lines with poliomyelitis viruses. Journal of Experimental Medicine 99, 167-199.

Evans, P. K. (1976). Higher plant protoplasts: isolation and properties. In Microbial and Plant Protoplasts, vol. 1, pp. 51-69. Edited by J. F. Peberdy, A. H. Rose, H. J. Rogers \& E. C. Cocking. London: Academic Press.

Garnham, P. C. C., BAKer, J. R. \& Bird, R. G. (1962). Fine structure of cystic form of Toxoplasma gondii. British Medical Journal 1, 83.

Gustafson, P. V., Agar, H. D. \& Cramer, D. I. (1954). An electron microscope study of Toxoplasma. American Journal of Tropical Medicine 3, 1008-1021.

Hartmann, W. \& Galla, H. J. (1978). Binding of polylysine to charged bilayer membranes. Molecular organizations of a lipid peptide complex. Biochimica et biophysica acta 509, 474-490.

Hughes, H. P. A. \& VAN KNaPen, F. (1982). Characterisation of a secretory antigen from Toxoplasma gondii and its role in circulating antigen production. International Journal of Parasitology 12, 433-437.

Kilejian, A. \& Jensen, J. B. (1977). A histidine-rich protein from Plasmodium falciparum and its interaction with membranes. Bulletin of the World Health Organization 55, 191-197.

LUFT, J. H. (1961). Improvements in epoxy resin em- bedding methods. Journal of Biophysical and Biochemical Cytology 9, 409.

LyCKe, E., CARlberg, K. \& Norrby, R. (1975). Interactions between Toxoplasma gondii and its host cells: function of the penetration enhancing factor of Toxoplasma. Infection and Immunity 11, 853-861.

MamelaK, M., Wissig, S. L., Bogoroch, R. \& EdelmanN, I. S. (1969). Physiological and morphological effects of poly-L-lysine on the toad bladder. Journal of Membrane Biology 1, 144-176.

Morgan, H. C. (1970). A survey of commercially available tissue culture media. In Vitro 6, 89-108.

NoRRBY, R. (1970). Host cell penetration of Toxoplasma gondii. Infection and Immunity 2, 250-255.

Schneider, U., SChWENK, H. J. \& BorNKamM, G. (1977). Characterization of EBV-genome negative 'null' and ' $T$ '-cell lines derived from children with acute lymphoblastic leukemic and leukemia transformed non-Hodgkin lymphoma. International Journal of Cancer 19, 621-626.

Sheetz, M. P. \& Singer, S. J. (1974). Biological membranes as bilayer couples. A molecular mechanism of drug-erythrocyte interactions. Proceedings of the National Academy of Sciences of the United States of America 71, 4457-4461.

WERK, R. \& Fischer, S. (1982). Attempts to infect plant protoplasts with Toxoplasma gondii. Journal of General Microbiology 128, 211-213. 